\title{
Medicine and Otorhinolaryngology in Ancient Egypt
}

\author{
Prof. Hesham Negm \\ Chairman of ORL department, Faculty of Medicine, Cairo University, Egypt
}

M edicine has always been one of the most honorable professions throughout history and, it has been known since the beginning of the existence of mankind on Earth. It took different forms and types according to the needs in each time, related to magic, to religion, etc.

Medicine was advanced and physicians acquired a highly respectable position in Ancient Egypt. Because the ancient Egyptians believed in the afterlife, they did every effort to preserve the human body in good condition by medical and surgical measures during life, and with mummification after death (Figure 1).

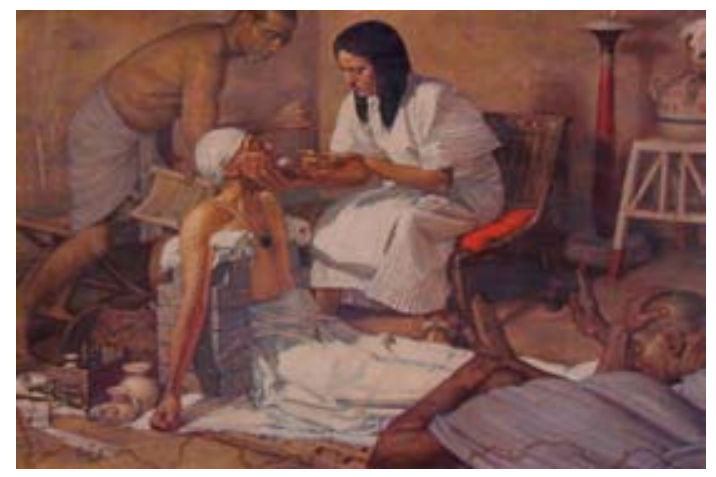

Fig. 1. Ancient Egyptian physician

The medical knowledge continued to grow and develop until the Hellenistic era, when Alexandria, with its famous library became the center of science and education in the ancient world.

We will start with Imhotep. Imhotep was the Minister of King Zoser, the founder of the Third
Dynasty, and he was the Chief Architect who built for his King the Step Pyramid in Sakkara, the first stone building in the world. He was the most famous Egyptian physician, also architect, astronomer and magician. Considered as the son God Betah, the creator of the God of Memphis. The chief priest of Heliopolis, and the chief physician and architect. Later, he was elevated to God of Medicine (Figure 2).

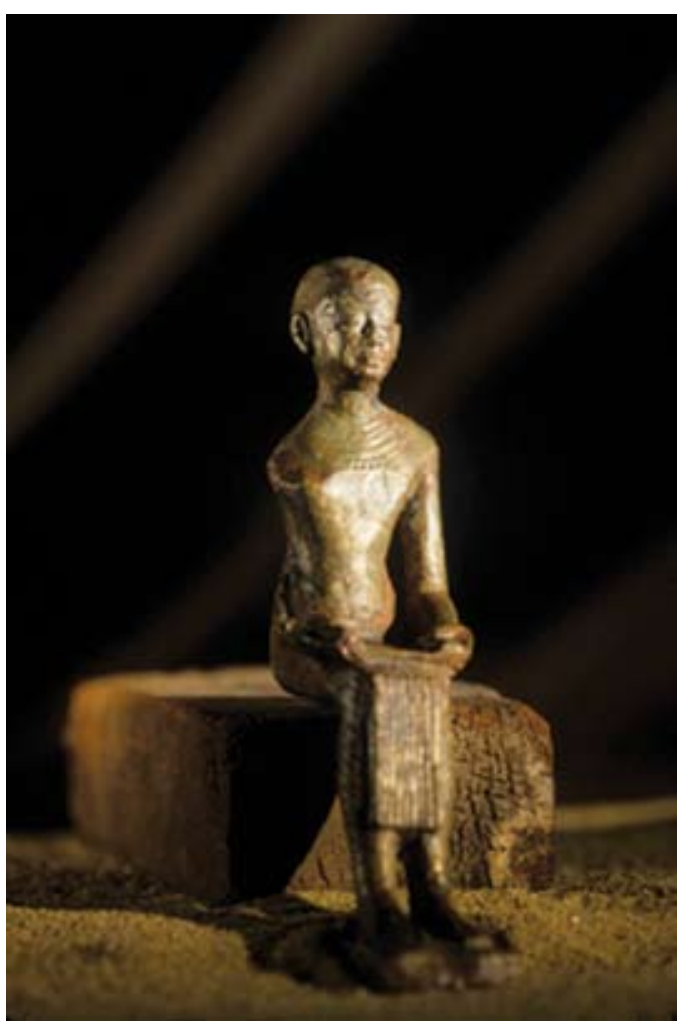

Fig. 2. Imhotep God of Medecine 
Then we had Hesi-Re. Recent research has shown evidence that Hesi-Re was the first Egyptian who bore the title of physician or SENW. He was a contemporary of Imhotep and probably deserves the title of "Father of Medicine". He carried the following titles: Chief of dentists, Chief of physicians, Royal scribe, known to the King and Priest of God Horus.

Then we had Ny Ankh Re. He was a royal physician who lived during 5th Dynasty. From the unique position of his statue the Egyptologists believed that he was concerned with medical education at his time.

Around the Pyramid's plateau in Giza (Figure 3), the tombs of the workers, or the pyramid builders were recently discovered. In the X-Ray pictures of some of the skeletons found in the tomb of the workers we

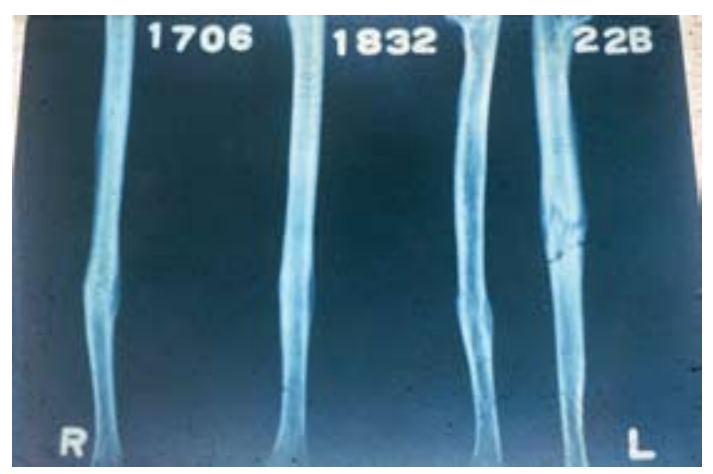

Fig. 4 A. X-Ray reduced/healed fractures

In the Sakkara Necropolis, tombs of the Royal Dentists were recently discovered during excavations made in 2006. They discovered three tombs. The most important was a tomb of dentist Emry. In the same area of the Sakkara Necropolis, they also discovered the tomb of physician Qar. Qar was a physician of the Royal Court, dating back to the

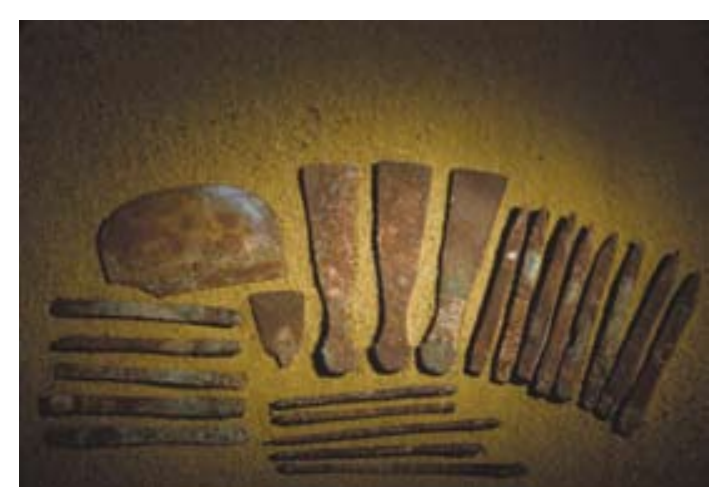

Fig. 5. Qar's Surgical instruments can see reduced and healed fractures, (Figure $4 \mathrm{~A}$ and B). denoting the knowledge of orthopedic practice during this time. Also another skeleton specimen, shows a trephine operation in the skull.

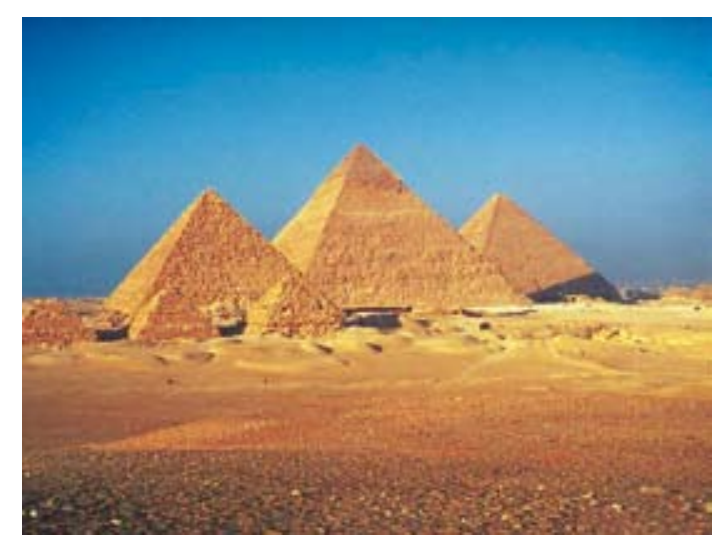

Fig. 3. The Pyramids of Giza

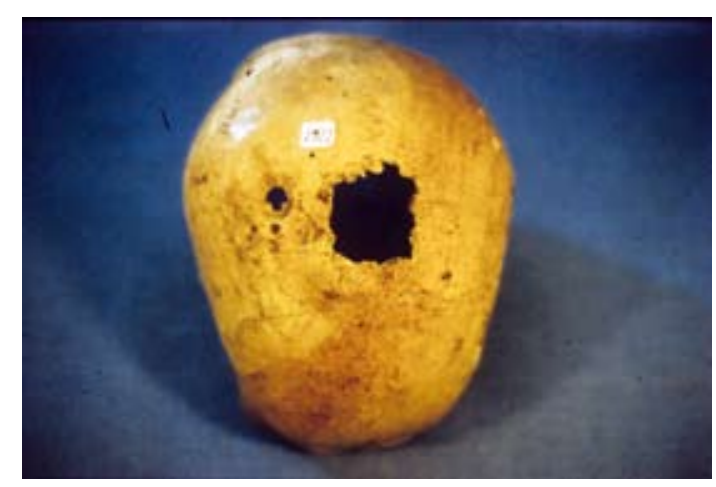

Fig 4 B.Skull with trephine surgery

time of the $6^{\text {th }}$ dynasty. His tomb is in the form of one Mastaba, built of mud bricks. In the interior of Qar's Tomb, they discovered his surgical instruments. made of bronze (Figure 5). In a another tomb of Ankh Ma-Hor from the 6th Dynasty, drawing on the wall shows the operation of male circumcision (Figure 6).

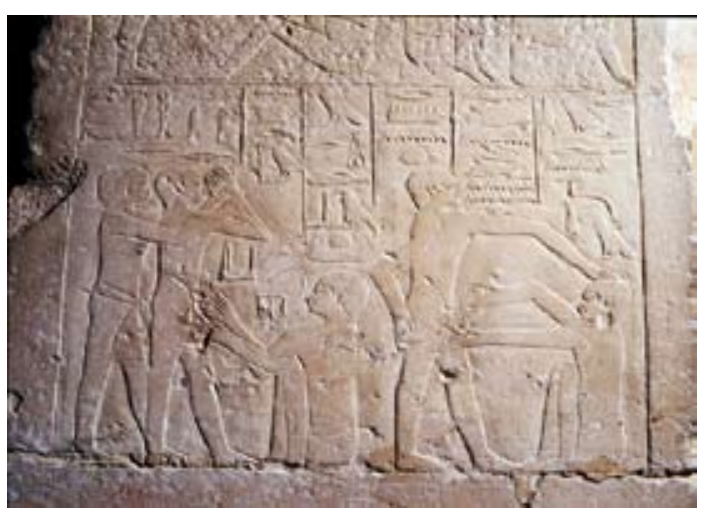

Fig. 6. The Circumcision surgery 
From Dandara Temple there is a limestone stela, that it is now present in the Louvre Museum in France, showing a woman in delivery, being helped by the Goddess Hathor. She is seated on the labor chair (Figure 7). A wall from Kom Ombo temple shows the queen during labor in the form of the Goddess Isis, and she is also seated on the labor chair. The ancient Egyptians used to keep the pregnant women 2 weeks before and 2 weeks after delivery in a clean, well aerated place called "mamisy" to protect them from infection and to give them the best care.

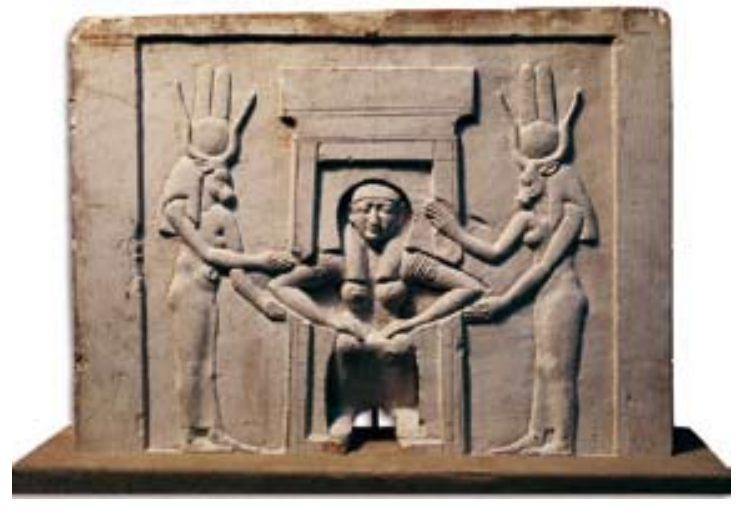

Fig. 7. Lady in delivery helped by Godess Hathor

Then we come to the masterpiece. This is, the first known evidence or reconstructive surgery, where we can see a wooden big toe fixed to the foot of a mummy (Figure 8). This specimen is now present in the Egyptian museum in Cairo.

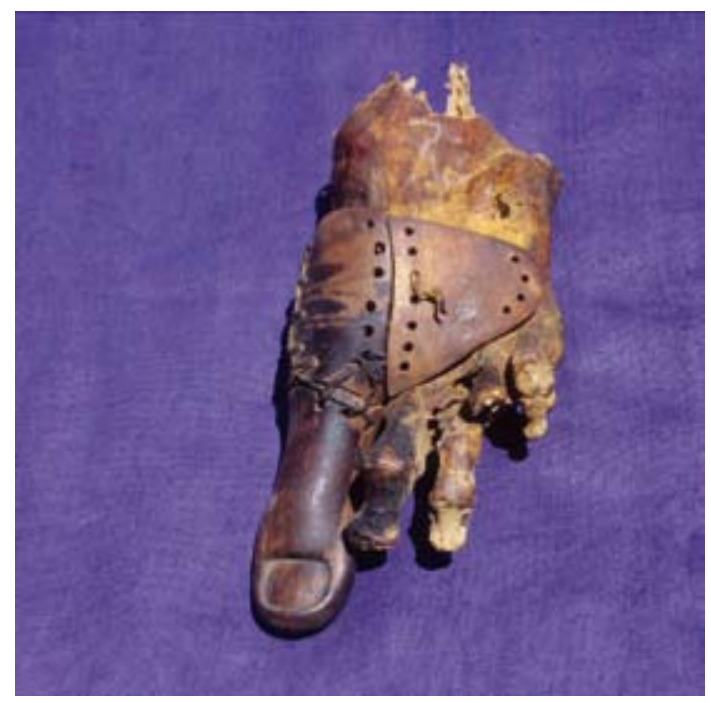

Fig. 8. Big toe prosthesis
The Medical Papyri are the first medical texts, dated from late $12^{\text {th }}$ to $20^{\text {th }}$ Dynasty $(1993-1090 \mathrm{~B}$. C). They have been written relatively late, but most of them reflect older knowledge as far back as the 4th Dynasty. Seven medical papyri are well known:

The Kahun Gynecological Papyrus

The Ebers Papyrus of internal medicine

The Edwin Smith Surgical Papyrus, the most famous

The Hearst

The Chester

The Berlin, and

The London

The Ebers internal medicine papyrus is the longest papyrus ever. It's length is more than 20 meters and it contains 877 remedies. It is written in Hieratic. And now it is present in Leipzig University Library.

The famous Edwin Smith Papyrus, is much shorter, although the still preserved part is about 4.7 meters and it contains 48 surgical treaties, and it is now present in New York Academy of Sciences (Figure 9). It is written in a more scientific script than the Ebers papyrus. It is an incomplete copy of an older reference, manuscripts dating from the Old Kingdom. This conclusion is based on gramatical features and archaic terminology in the way it has been written. It is supplemented by numerous glosses, which constitute the most valuable part of the papyrus. The surviving text systematically details the treatment of trauma in descending anatomical order, from the top of the head to the vertebrae. The preserved 48 cases are arranged in a coherent pattern, specifying the bedside manner of the Egyptian physician. Following each title, a description of the examination begins with the phrase "If you examine a man who has so and so", and continues with a detailed list of symptoms and steps of examination. Then the physician pronounces an oral diagnosis, an assessment of the patient's chance of survival, by stating either: "An ailment which I will treat", or "An ailment with which I will contend", or "An ailment not to be treated" so the patient will die. When considered feasible, treatment is described in the final section. We will give some examples from Edwin Smith's papyrus concerning several otorhinolaryngological cases. 


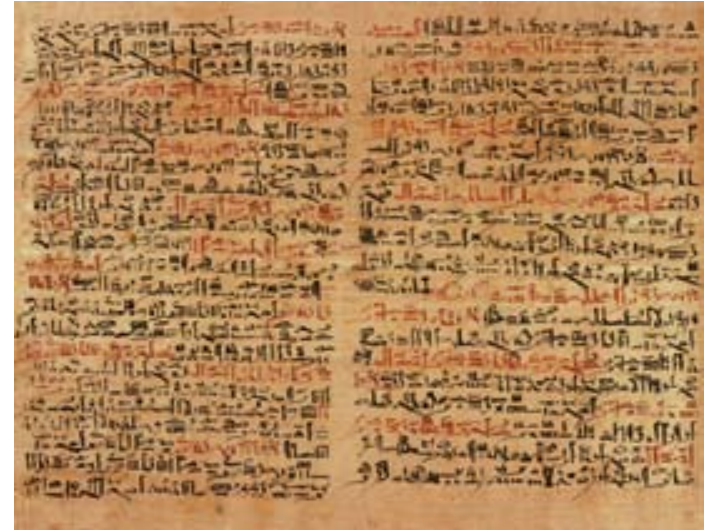

Fig. 9. Edwin Smith Papyrus

\section{Case \# 1}

\section{Instructions concerning a break of the column of the nose}

- Examination: If thou examinest a man having a break of the column of his nose, with disfigurement, and depression, and has discharged blood from his nostrils, you should say: "One having a break of the column of his nose, an ailment I will treat."

- Treatment: So clean the nose with 2 plugs of linen, place 2 other plugs of grease saturated linen in the 2 nostrils, bed rest until the swelling subside, apply stiff rolls of linen to hold the nose fast and treat with honey and grease until he recovers.

Honey was used as an antiseptic at that time and grease as we are using now Vaseline. So, it's the same idea but with different materials.

\section{Case \# 2}

\section{Instructions concerning a break in the chamber of his nose}

- Examination: If thou examinest a man having a break in the chamber of his nose, with his nose bent, and face disfigured, you should say: "One having a break in the chamber of his nose. An ailment I will treat."

- Treatment: Force it to fall in, to lie in its place, (like reduction). Clean the inside, apply 2 grease saturated plugs of linen, and place 2 stiff rolls of linen, bound on, and treat with honey, grease and lint until he recovers.

\section{Case \# 3}

\section{Instructions concerning a smash in the nostril}

- Examination: If thou examinest a man having a smash in his nostril, put your hand upon the nose, should it crepitate under the finger, while he discharges blood from his nose and ear on the side of smash, and he is speechless, ( he is having a fracture base).

- Diagnosis: You should say: "One having a smash in his nostril. An ailment not to be treated." So at that time, this man would die.

\section{Case \# 4}

\section{Instructions concerning a wound in his nostril}

- Examination: If thou examinest a man with a wound in his nostrils piercing through, you should find the 2 lips of the wound and stitch together. You should say: "One having a wound in his nostril, piercing through, an ailment which I will treat."

- Treatment: Make 2 swabs of linen, clean every worm of blood, bind with fresh meat until the stitches loosen,(like debridement), and treat with honey, grease and lint until he recovers.

\section{Case \# 5}

\section{Instructions concerning a wound in his ear}

- Examination: If thou examinest a man having a wound in his ear, cutting through its flesh, the injury being in the lower part of his ear and confined to the flesh, you should draw it together with stitching behind the hollow of his ear. Then should say: "One having a wound in his ear, cutting through its flesh. An ailment which I will treat."

- Treatment: If you find the stitching of that wound loosen, stick in the two lips of his wound, then you should make for him stiff rolls of linen and pad the back of his ear. Then you should treat it afterwards with grease, honey, and lint every day until he recovers.

\section{Case \# 6}

\section{Instructions concerning a wound in his throat}

- Examination: If thou examinest a man having a gaping wound in his throat piercing through to his gullet; if he drinks water he chokes and it comes out of the mouth of his wound; it is greatly inflamed, so that he develops fever from it; you should draw together that wound with stitching. You should say then, concerning him: "One having a wound in his throat, piercing through to his gullet. An ailment with which I will contend." 
- The first treatment: You should bind it with fresh meat the first day. You should treat it afterwards with grease, honey, and lint every day, until he recovers.

Second examination: If, however, you find him continuing to have fever from that wound, you should apply dry lint in the mouth of his wound, and moor him at his mooring stakes until he recovers.

These were some examples of cases from the Edwin Smith papyrus, and we can note that many of them had the same strategy of treatment like we are using nowadays.

Then we will move to the last part, which is about mummification, or preserving the body after death. In a very nice, colorful picture. which is a painting from a wooden sarcophagus, we can see the embalmer, in the form of God Anubis with the head of a jackal performing mummification (Figure 10). between Isis and Nephtysl.

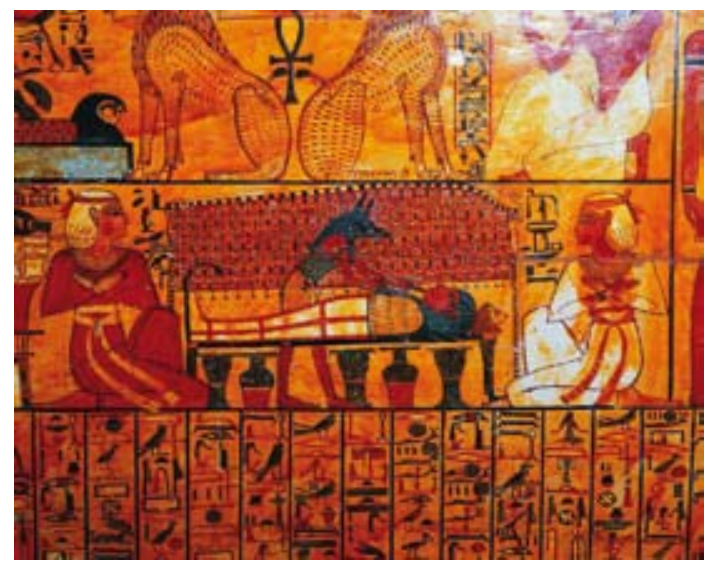

Fig. 10. Mummification

The first convincing evidence of a successful intentional mummification occurred in the 4th dynasty, in the tomb of Queen Hetepheres in Giza. The two crucial steps to arrest the decomposition of the body were evisceration and dehydration of the tissues. There were only two major additions to these basic procedures. The first innovation was excerebration, practiced in some mummies by inserting a metal hook into the cranial cavity through the nostrils and ethmoid bone; to remove the contents of the head. The second innovation was introduced in the $21^{\text {st }}$ dynasty, when they used subcutaneous filling materials trying to retain the original body contour to some extent. They kept the internal viscera after removing them from the body in 3 Canopic Jars (seen under the embalmers table in fig. 10). Figure 11 shows an Egyptian mummy, and we can see that the body is in a relatively good condition after thousands of years.

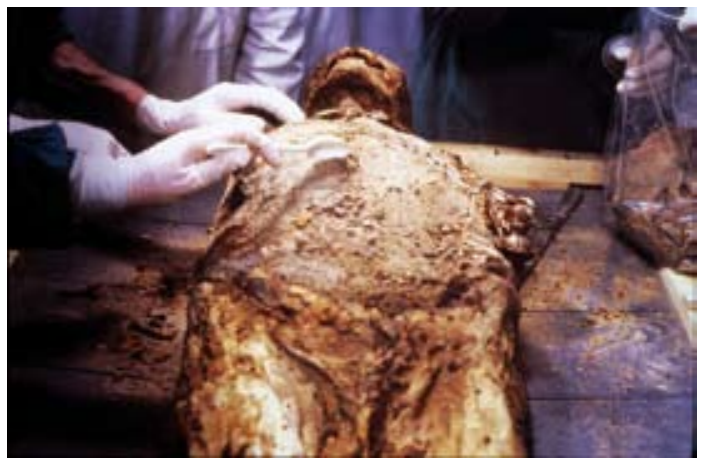

Fig. 11. One of the Egyptian Mummies

The information about mummification came to us through Herodotus, but recent studies using the CT with $3 \mathrm{D}$ reformatting and volume rendering techniques showed us some more information. For example, examining through multi slice CT the body of Tutankhamun, it was discovered that he was not murdered by a blow to his head as they knew before. There is no evidence for partially healed injury to the back of the skull. The hole in the skull (Figure 12) could not have come from an ante-mortem injury. This hole is most probably made by the embalmers as the second route to introduce their materials through the skull.

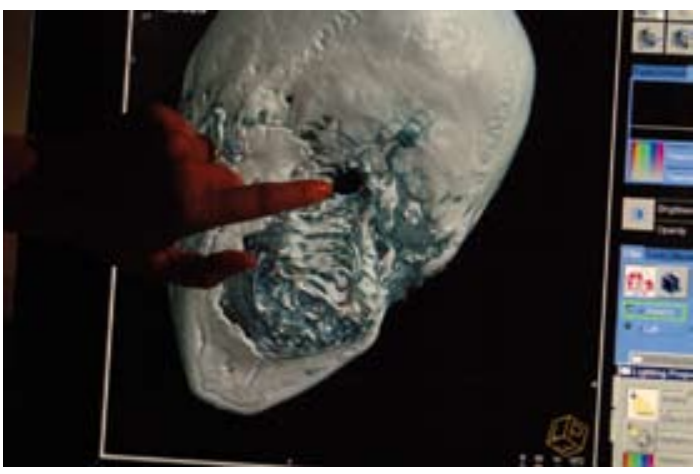

Fig. 12. Tutankhamun scan

Tuthmosis III, one of the most powerful kings (Figure 13) was scanned and the reports showed that he developed atrophic rhinitis (the nasal turbinates were very small). Also his estimated age was 4560 years, his estimated height was $1,75 \mathrm{~cm}$ and his skull was relatively elongated backward, dolichocephalic (Figure 14). 


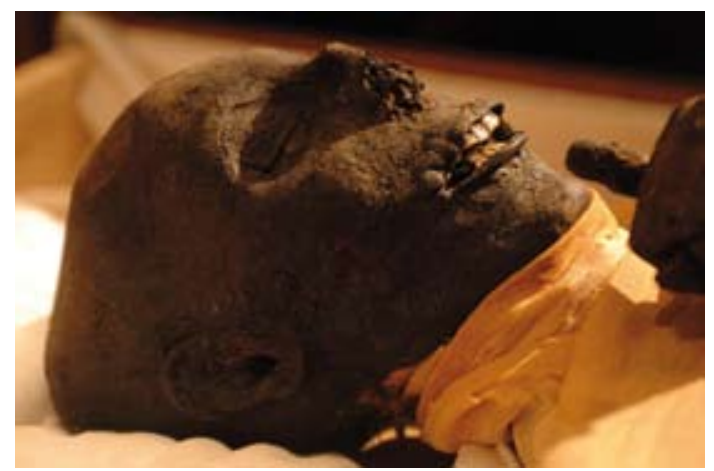

Fig. 13. Tuthmosis

In conclusion, medicine in Ancient Egypt was only one aspect of a great civilization. The medical skills of ancient Egyptians were far advanced beyond their time. They wrote the first medical texts, performed the first surgical techniques, used the

\section{Recommended readings}

1. Nunn JF. Ancient Egyptian Medicine. The British Museum Press, London 1996.

2. Bardinet T. Les Papyrus Mŭdicaux de l'Egypte Pharonique. Fayard Paris 1995.

3. Andrews CAR. Egyptian Mummies. British Museum Publications, London 1984.

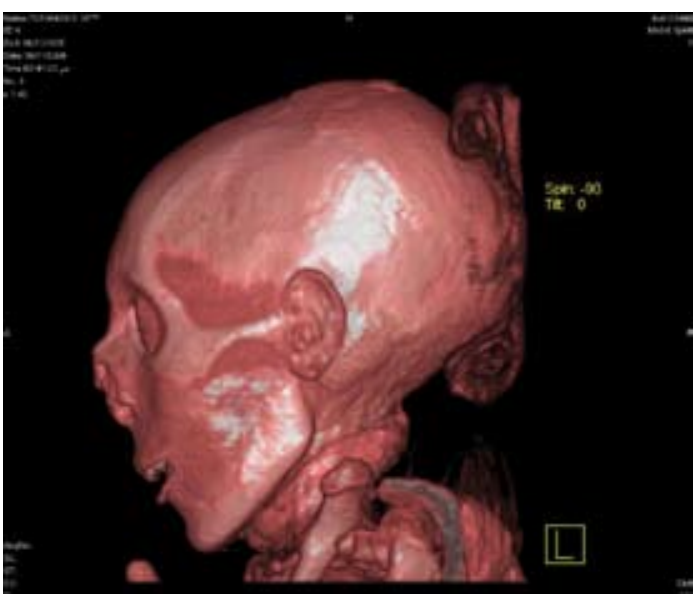

Fig. 14 Tuthmosis skull

first splints and bandages, and used the first drug therapies. The ancient Egyptians revolutionized the world of medicine and laid the framework for the advances in medicine that exist in our world today.

4. Breasted JH. The Edwin Smith Surgical Papyrus. University of Chicago Press, Chicago 1930.

5. Jonckheere F. Les Medecins de L'Egypte Pharaonique. Fondation Egyptologique Reine Elizabeth, Brussels 1958. 